\title{
Digital Media and the Convergence of Geographic Cultures
}

\author{
Marcus Schulzke
}

\section{Introduction}

Urbanization is one of the themes of modernization and a central concern for contemporary social theory (Lefebvre 1991; Saunders 1995). It proceeds at different speeds and through different mechanisms depending on the context, but urbanization in some form is nearly universal among developing countries (Clark 1996). The process usually involves a profound social shift as workers leave the country and take up new lives in cities. Traditional forms of association are broken and the deracinated migrants must construct new lives in an open-ended urban setting (Inkeles and Smith 1974). Among the effects of urbanization is the formation of two distinct, often antagonistic human environments: the city and the country.

For many social theorists, the city and the country are distinct worlds (Soja 1989; Williams 1975). Some portray the former as progressive and cosmopolitan in contrast to the reactionary and parochial country (Horkheimer 2002; Marx 1990). Others claim that city life is morally corrupt and that rural communities offer genuine associational life (see Short 1991: 45). The distinct modes of production, level of exposure to other cultures, and relationships to nature are credited with encouraging different forms of life. The details of this thesis vary, but the existence of two or more distinct cultures, shaped by built environments, is widely accepted (Short 1991).

The physical differences between city and country, like population density and extent of construction, may not disappear in the near future. However, the social effects attributed to these environments are not necessarily connected to anything physical. Among the cultural differences attributed to the city and the country are their distinct relations to nature, modes of production, levels of tolerance, and ranges of free expression. Differences of the first and second sort have already been largely eliminated but the third and fourth are still pronounced. Tolerance and individualism are often associated with cosmopolitan urban spaces, but new technologies, especially the internet, have the potential to change this. Television has produced some cultural convergence, but tends to do this in a negative way, eliminating difference without replacing it with any new forms of expression. Networked technologies have the potential to overcome spatial limitations in a more positive way. Consequently, city and country may become different geographic spaces that lack the distinct forms of life these geographies once helped to produce. The digital space is neither urban nor rural, but it shares many of the characteristics of the former and has the potential to affect a convergence of geographic cultures.

\section{Theorizing Human Environments}

The relation between city and country was of central importance for modernization theorists well into the twentieth century (Angell 1951; Gerschenkron 1962; Lipset 1959; Miner 1952; Wirth 1938). Many judge the rise of cities as a positive, albeit painful, stage of historical progress. Communists invoked it as a moment in the story of the supersession of the feudal order (Gramsci 1992; Marx 1978; Marx 1999). Fascist futurists like Filippo Marinetti 
celebrated the resulting industrialization and mechanization of life (2006). A range of liberal, conservative and reactionary theorists have favored traditional forms of life, epitomized by small, rural communities or have considered cities dangerous sites of civil unrest (Short 1991: 109-125). However, even those who oppose urbanization or are skeptical of its consequences have generally accepted the terms of the discourse and argued from the assumption that societies are geographically bifurcated (Rousseau 2003).

Many social theorists have been enthusiastic about the long-term effects of urbanization. In some cases, there is outright hostility to the old modes of life represented by those in the country. For example, the normative project of overcoming agrarian life is one of the themes of Marxist scholarship. Marx could find no place for the peasantry in the socialist state and therefore classified it as an essentially reactionary class that had to be absorbed into industrial society (2008). More recent Marxists like Horkheimer and Gramsci advocate urbanization as a means of destroying traditional life and overcoming conservatism (Gramsci 1992; Horkheimer 2002).

Raymond Williams argues that the contrast between the two worlds is central to modern consciousness (1975). According to him, it helps people conceptualize what is gained and lost through progress. He thinks that the perception of the two spheres is largely based on myth but it is a myth that helps us cope with the troubles of modernization. By his account, which focuses on the literature of nineteenth century England, the city is represented as an evil place, and the country an idyllic homeland. In the twenty-first century, the country continues to represent the lost natural existence, but the city is usually the favored sphere with the benefits of progress outweighing the loss of tradition. Contemporary cities stand as symbols of modern technology and the dream of a human environment safe from a capricious natural world (Kaika and Swyngedouw 2000).

Williams is right to argue that the two spheres are less distinct than the ideal types imply. Culturally, there are many links between urban and rural residents of the same country. In most western countries, all citizens undergo similar programs of public education, consume the same media, speak dialects of the same language and are subject to the same national values. There is also a growing physical link between city and country, or rather, a blurring of the boundary between the two. Cities have become decentered as jobs have shifted toward the periphery in order to be easily accessed by suburban residents (Clark 2002). Moreover, the growth of suburban communities, which became particularly prominent in the $1990 \mathrm{~s}$, has added a third residential category in many areas.

In light of the growth of suburbs, erosion of urban spaces and emergence of new technologies, some poststructuralists have challenged the reality of urban environments and predicted their supersession. Virilio argues that telecommunications allows people to transcend space (1999). Whereas once space was something positive, a necessary precondition for association and political action, it has become a barrier. Virilio is correct in describing the changing character of space, but he exaggerates the extent to which space can be overcome. Much of life continues to take place in the physical world and probably always will. While the poststructuralist position that Virilio exemplifies has some merit, and is partially endorsed in this essay, it overstates the case by conflating profound social changes with a geographic change.

The expanding suburbs and changing character of the city blur the borders between city and country, but do not efface them. Work describing the growth of suburbs tends to reaffirm city and country as normative categories. While both city and country are presented as having faults and redeeming value, suburbs are maligned spaces (Daniels 1999). Objecting to them presupposes the existence of more authentic spaces, whether these are the natural spaces of the country or the associational spaces of the city. Indeed, any discussion of suburbs and decentered cities presupposes that there is still something left of the urban space, as these ideas depend on an oppositional concept that they can be defined against.

Perhaps the clearest evidence of the continuing relevance of the distinction between city and country is the role that it plays in contemporary political discourse. In the United States, antagonisms between city and country are still part of popular political discourse. Politicians routinely associate themselves with a small town background and associate cities with elitism (Alsayyad 2010: 85). Conservatives are the most eager to perpetuate this distinction. Their anti-intellectual rhetoric is often closely linked to anti-urban judgments (Beck 2003). The Tea Party movement shows the virulence of this way of thinking (Zernike 2010). New York in particular is singled out as an emblem of everything that conservatives oppose. They describe the city as if it were a foreign space that lies outside the "real America" (Carr and Kefalas 2009; Frank 2004). Although some of these claims may be purely rhetorical, the difference between geographic cultures seems to be a core part of the ideology of conservative populists. Their statements tend to be hyperbolic, overemphasizing the differences between regions, but the sentiment is informative, as it shows that many still see a cultural divide between the city and the country. 


\section{Enduring Differences}

The concentration of buildings and people make urban environments easily identifiable, but the cultural and structural qualities that arise from the physical characteristics of urban spaces are usually the foremost concerns for social theorists (Saunders 1995). Among the cultural characteristics used to distinguish the city and the country are different relationships to nature, modes of production, levels of tolerance and opportunities for personal expression. These four distinguishing features are by no means the only ways of differentiating the geographic cultures, but they are among the most popular and this makes them a useful starting place for analysis (Binnie, Holloway, Millington, and Young 2006; Groth and Corijn 2005; Soja 1989; Young, Diep, and Drabble 2006). The accuracy of these cultural distinctions can be assessed by examining the extent to which they still unique to one environment.

The proximity to nature is both a physical and cultural characteristic of rural life because being physically close to the natural world is may create a psychological or spiritual connection it or to a more primitive form of life (Holloway and Hubbard 2001). This distinguishing feature of rural life tends to be invoked by those who lament something that was lost in modernization. However, the glorification of the rural may be unique to the outsider, as it generally comes from those who have lived in cities (Williams 1975). It is the product of those so far removed from a form of life that they can imagine it without fault. As Raymond Williams explains, natural country life is a myth constructed as the alternative to the anomic city of the industrial revolution (1975).

The idea of the natural country and unnatural city is largely mythical. Land outside cities is profoundly affected by human interference. Pollution, human intervention in the development plant and animal species, and the marks of resource extraction have rendered natural world less natural than it may appear to be (McKibben 2006, Barry 2007). By contrast, cities can provide some experience of the natural world. They often have parks, zoos, and aquariums that can simulate other environments and house a diverse range of plant and animal species. In fact, when measured in terms of diversity, cities are superior to some rural areas, especially rural areas that have been heavily farmed (Wolch 2002). Thus, the proximity to nature is inadequate for marking the difference between city and country, as either a cultural or a geographical feature.

Marxists tend to consider the city an artificial space, but this is judged favorably, as this is the source of the city's liberating potential. Marx and Engels define city and country by the divergent modes of production (1978). The city is industrial; the country is agricultural. The former is dominated by a class struggle between the bourgeoisie and proletariat, while the latter is home to the decaying feudal classes of the aristocracy and peasantry. Marx draws a sharp binary, defining the two environments to separate moments of history. However, a strict Marxist interpretation is untenable in the twenty-first century because of the industrialization of the agriculture and the diversification of work in cities.

As Marx predicted, capitalism has transformed agricultural production. Over the past century, it has been heavily industrialized. Farms now resemble factories, with complex divisions of labor and little respect for biodiversity (Pollan 2006). Consequently, a Marxist could explain agrarian production in terms of the same class relationship as urban production. The character of work in cities has also changed dramatically. Most city-dwellers work in the service sector as production jobs become increasingly scarce (Kasarda 1995: 239). Furthermore, digital technologies allow many jobs requiring intellectual labor to be performed anywhere. Postindustrial cities are increasingly becoming areas of consumption rather than production (Zukin 1998). Thus, it is difficult to define urban, suburban and rural spaces by their modes of production, as the modes of production have become more similar and work has become less attached to a geographical space.

A more promising reason for cultural divergence is that there are different educational opportunities for people living in different areas. Whether or not formal education is the same for residents of urban and rural communities, education outside a formal academic context can differ immensely. Small towns may offer few opportunities to interact with people from foreign countries or who follow different value systems. Although many small communities, especially those along borders, have ethnic diversity, it tends to be more limited than the heterogeneous mixture of peoples in cities (Colombijn and Erdentug 2002; Soja 1989). Urban-dwellers, especially those in cities with large immigrant populations, have myriad opportunities to learn about other cultures, especially when the city has large immigrant communities that preserve foreign traditions (Bollens 2007: 20). Robert Paul Wolff describes cities as places uniquely suited for encouraging toleration. They are cosmopolitan places because of their "size, functional differentiation, speed of movement, fragmentation of social groupings, and density of population" (1968: 140). Some urban spaces have been even designed to encourage random encounters and to promote toleration (Donald: 
138).

The close contact between different ethnic groups in cities is not always peaceful. It can lead to isolation and violence. Some have suggested that cities are less suited to cosmopolitan life than they were in the past because of increasing compartmentalization and conflict between groups (Sibley 1995). However, segregation into ethnic neighborhoods and conflict between ethnic groups living in cities is hardly a new phenomenon; these are themes of urban life (Mumford 1961). Even at their most divided, cities at least provide the potential for interaction between groups - a potential that is lacking in many small communities. Moreover, empirical studies suggest that the diversity of the city does have a positive effect on tolerance for most residents (Tittle and Grasmick 2001; Wilson 1991).

Aside from the distance from nature, one of the most popular criticisms of urban life is that it is alienating. This claim is found at least as far back as Durkheim's study of suicide and his argument serves as the basis for many later studies (1997). Kevin Lynch attributes the alienation to inhabitants' mental representation of their environment. By his account, cities are not intrinsically alienating; whether they have this effect is determined by how they are structured. The alienating city is one that lacks landmarks or distinctive features that can be used as reference points with which to locate oneself and create a mental map of a space (Lynch 1960). Others find that the norms that govern interaction between people in crowded spaces can be alienating. Among the most prominent examples of this are the deliberate displays of inattention people use to navigate urban spaces, such as avoiding eye contact with others and limiting conversation with strangers (Goffman 1959; Lofland 1998). These forms of alienation seem to be largely negative, but alienation produced by isolation can be empowering as well.

If one defines freedom negatively, as an absence of restraint, then the large, anonymous city is almost utopian. In them one finds "an atmosphere of expanding personal freedom and individual opportunity" because they weaken or sever the premodern ties to kinship and land and allow individuals to replace these with any meanings they choose (Barth 1980: 3). In this way, cities are powerful tools for self-creation. The myriad opportunities they present allow for experimentation with different identities. In fact, Barth argues that there is a historical link between the cities and interest in individual freedom (1980: 16).

Wolff links the cosmopolitanism of the city to its anonymity, making the latter a precondition of the former. Anonymity allows one to experiment with different identities and become part of new groups that support them. The country, by contrast, is a place that a classical liberal like John Stuart Mill would find repressive because of the community involvement in personal affairs.

It is a commonplace that in the anonymity of the big city one can more easily assemble the precise combination of tastes, habits, and beliefs which satisfy one's personal desires and then find a circle of friends with whom to share them. In the small town or suburb it is impossible to escape from the sort of social interference in private affairs which Mill condemned (Wolff 1968: 140).

The anonymity of cities is still a meaningful way of differentiating city from country. One might object that it is easy to become anonymous in the country by avoiding small communities and living completely alone in a remote area. This is true, but the kind of anonymity produced is somewhat different. One can escape from the watchful eyes of others by living in isolation, but this is not the same as the empowering anonymity of the city. The strength of urban anonymity is in the capacity to act without interference and to still be in a place that offers opportunities to make use of this liberty.

There are other ways for distinguishing city and country, but these four are among the most commonly cited by social theorists. The first two, which define the environments by their proximity to the natural world or the mode of production, are poor candidates for describing the relation at present. The others, urban cosmopolitanism and the anonymity facilitating self-creation, continue to be important byproducts of urban life. Nevertheless, as the next section will show, new communications technologies create the potential for these to be more accessible qualities that are not confined to a particular geographic space.

\section{| Digital Technology and Cultural Convergence}

The benefits of city life are closely linked to the physical environment, but this link does not entail an essential connection between them and the environment, nor does it mean that there is only one way of producing the positive effects described in the previous section. The connection between an environment and a culture may appear 
necessary, but only because earlier levels of technology did not permit the transcendence of space. Until the final decades of the twentieth century, environments could be exclusively defined by the physical spaces, but with the rise of networked technologies people spend much of their lives living outside the spaces they occupy physically (Yee 2006b). With increasingly easy access to networked technologies, it is possible for alternate spaces to erode the cultural barrier between city and country by making benefits of urban life widely available.

Although, some scholars argue that the categories of space and time have become compressed or that they are nearly meaningless (Robbins 1988; Virilio 1999) it seems unlikely that space will cease to matter. Our bodies and the technologies for overcoming spatial constraints must occupy physical locations and be subject to spatial influences. A more plausible thesis is that the physical world is no longer the only one that people inhabit. As Bolter and Grusin explain, someone who lives a networked life can lead multiple lives simultaneously - one in the physical world and others in cyberspace (2000: 232). Networked people tend to be less connected to their physical and cultural surroundings and to their daily interactions with others, yet they are engaged in networks that transcend these surrounding (Varnelis and Friedberg 2008). Thus, the prevalence of networked technologies challenges the city and country dichotomy by creating a virtual space that residents of the city, country, and suburb can each occupy while still living in their respective geographic locations

With those living in different physical spaces increasingly occupying the same digital world, differences between urban and rural cultures will likely diminish. There are good grounds for expecting such a change based on the changes initiated by older media. Studies of nationality show that widely distributed print media was instrumental in replacing local identities with large group identities (Anderson 1983; Deutsch 1953; Gellner 1983). Critics of film and television have argued that these also have a standardizing effect on audiences (Adorno and Horkheimer 1969; Adorno 1991a; Adorno 1991b). The weakness of television and other traditional media as means of producing cultural convergence is that they tend to also reproduce hierarchical power relations (Ito 2008: 3). These media are created and distributed by a relatively small collection of firms and given consumers who are usually denied the right to modify the content. By contrast, networked media, which use what Ito calls a "many-to-many" form of distribution (Ito 2008: 7), are far more open to user created modification and decentralized communication (Benkler 2006; Jenkins 2006a; Jenkins 2006b; Russell, Ito, Richmond, and Tuters 2008). As Lim and Kann put it, "Networked cultural production assails traditional structures of authority and disrupts the received logic of consumption by breaking down barriers between consumers and producers" (2008: 71).

Networked technologies are well suited to providing some of the benefits that follow from urban life to those who are geographically isolated. The internet is a profoundly cosmopolitan space, since anyone with an internet connection is capable of communicating with people of almost any background. Even people living in countries with restrictions on internet use often find ways of circumventing filters and communicating with outsiders (Zha and Perlmutter 2008: 281). In fact, the internet surpasses cities as a cosmopolitan space because it allows contact with a broader range of people than one would find in even the most diverse location. More importantly, when people are online the many-to-many mode of distribution means that they are encouraged to communicate with each other, rather than simply gathering information from common sources. They can watch Youtube videos from places they cannot visit, find new friends on Facebook, or read strangers' blog posts; they can also produce their own videos and blog posts for others to view.

The widespread use of networked technologies and the decentralized modes of transmitting information facilitate random encounters between individuals who would not usually interact. Moreover, they often encourage interaction in settings that provide incentives for engaging in group activities that encourage mutual understanding. Massively Multiplayer Online Role-playing Games (MMORPGs) are one of the most prominent examples of this. Players find new friends from other regions or from foreign countries and work alongside them in completing quests and forming teams or guilds. The existence of common interests that can only be fulfilled by cooperating with others makes association a prerequisite for playing many of these games, especially as players become more advanced. In some cases, individual games can even be like virtual cities. As Humble points out, the MMORPG Everquest alone has so many players that they would qualify as the United States' 35th largest city if they were located in one place (Humble 2004: 25). Networked fan communities, political interest groups, forums, and blogs are likewise sites of communication between people from diverse backgrounds who share common interests, making them ideal places for recreating urban cosmopolitanism (Jenkins 2006a; Jenkins 2006b).

A growing body of research suggests that the internet may help to overcome the decline of associational life by forming new online places where people can meet and interact (Rheingold 2000; Steinkuehler and Williams 2006; 
Bennett 2008; Dahlberg 2011; Schulzke 2011). These claims are often formulated as though networked technologies were compensation for something that once existed but was lost. However, networked technologies not only provide a means of replacing traditional associational ties, but also surpassing them by engaging people who live in rural and suburban areas where extensive contact with a diverse range of people is more difficult.

Networked technologies also have strong implications for self-creation and experimentation with identities. In this regard, they resemble city life. Urban and digital environments are prone to creating feelings of alienation, but the alienation can be empowering to the extent that isolation and anonymity are redeemed as preconditions for exploring or developing one's identity. When online, anonymity permits everything from discussion of controversial beliefs in a relatively secure setting to the creation of alternate personas.

Ethnographic research shows that users make excellent use of the online space as a mode of self-creation (Taylor 2006). Customizable websites and profiles give users a chance to create personalized spaces (Ellison, Steinfield, and Lampe 2007). Online video games and virtual worlds go even further, allowing players to create characters and represent themselves in an entirely new way (Boellstorff 2008; Cogburn and Silcox 2009; Taylor 2006; Wolfendale 2007; Yee 2006a). With so many people using the internet as a medium through which to experience a heightened sense of individual liberty and creativity, the city-dweller's ability transform in new contexts is no longer unique. One can replicate the experience online by engaging with other people in digital communities. Someone with few opportunities to experiment with different identities, or even someone confined to a homogenous or intolerant place, may find respite in the anonymous liberty of networked technologies.

\section{Conclusion}

Although the line between the city and the country has blurred, physical and cultural differences persist. Urban spaces suffer from many shortcomings - they can be crowded, polluted and plagued by high levels of crime - but cities can also be open and diverse environments that create myriad avenues for self-creation and cultural exchange. These benefits of urban life have, until recently, been confined to cities. However, they have become more widely available as networked technologies have allowed users to transcend their locations in space. These technologies may affect a convergence of geographic cultures as users interact in settings that mirror the cosmopolitanism and anonymity of urban spaces.

Although this essay is primarily concerned with the benefits associated with urban life becoming generally accessible, technological development is not uniformly positive. The rise of digital technologies can also damage relationships within physical spaces. Living part-time in the digital world requires leaving one's own for the same duration. For some, the internet is so appealing and addictive that it leads to neglected responsibilities in the physical world. This problem is especially pronounced with video games, as those which recreate entire worlds online encourage constant play (Chappell, Eatough, Davies, and Griffiths 2006; Ng and Wiemer-Hastings 2005). Overindulgence in the digital world threatens any goods provided by ones physical environment. Thus, it is essential to limit the normative force of the argument. Networked technologies have enormous potential as means of temporarily transcending the limits of physical space, but enthusiasm for them should always be checked by attention to the costs of excessive use.

It is also important to remain skeptical of some of the interests that regulate the internet. While Mitchell is right to claim that "cyberspace is profoundly antispatial" (Mitchell 1995: 8), it is possible to understand the problems digital spaces by drawing analogies from scholarship dealing with physical spaces. Many of the same problems Weberian and Marxist scholars found in cities have reappeared online. Weberian analysis, which focuses on gatekeepers and their control over territories and resources, is just as relevant to networked technologies as it was in describing the dynamics of urban life. Users of these technology are forced to access digital spaces through gatekeepers and by means of the gatekeepers' technology, allowing business elites and governments to control access as effectively as in the past (Hindman 2009). The Marxist approach of exploring the connection between economic power and the distribution of space is relevant for the same reasons. Digital spaces are open to resource based discrimination, as new technologies allow for prioritized service to select individuals (Graham and Marvin 2001). Therefore, if networked media are to realize their potential of bridging geographic barriers, users must continually challenge attempts to impose limits akin to the ones that are responsible for unequal access in the physical world. 


\section{References}

Adorno, Theodor, Max Horkheimer. [1947] 1969. Dialectic of Enlightenment. New York: Continuum.

Adorno, Theodor W. 1991a. "Culture and Administration." Pp. 107-131 in The Culture Industry, edited by J. M. Bernstein. New York: Routledge.

Adorno, Theodor W. 1991b. “The Schema of Mass Culture.” Pp. 61-97 in The Culture Industry, edited by J. M. Bernstein. New York: Routledge.

Alsayyad, Nezar. 2010. The Fundamentalist City? Religiosity and Remaking of the Urban Space. New York: Routledge

Anderson, Benedict. 1983. Imagined Communities. New York: Verso.

Angell, Robert Cooley. 1951. "The Moral Integration of American Cities.” American Journal of Sociology 57(1): 92-100

Barry, John. 2007. Environment and Social Theory. New York: Routledge.

Barth, Gunther. 1980. City People: The Rise of Modern City Culture in Nineteenth-Century America. New York: Oxford University Press.

Beck, Glenn. 2003. The Real America: Messages from the Heart of the Heartland. New York: Pocket Books.

Benkler, Yochai. 2006. The Wealth of Networks: How Social Production Transforms Markets and Freedom. New Haven: Yale University Press.

Bennett, W. Lance. 2008. Civic Life Online: Learning How Digital Media Can Engage Youth. Cambridge, MA: MIT Press.

Binnie, Jon, Julian Holloway, Steve Millington, Craig Young. 2006. Cosmopolitan Urbanism. New York: Routledge.

Boellstorff, Tom. 2008. Coming of Age in Second Life: An Anthropologist Explores the Virtually Human. Princeton, NJ: Princeton University Press.

Bollens, Scott A. 2007. Cities, Nationalism, and Democratization. New York: Routledge.

Bolter, J. David, Richard Grusin. 2000. Remediation: Understanding New Media. Cambridge, MA: MIT Press.

Carr, Patrick J., Maria J. Kefalas. 2009. Hollowing Out the Middle. Boston, MA: Beacon Press.

Chappell, Darren, Virginia Eatough, Mark N. O. Davies, Mark Griffiths. 2006. “EverQuest - It's Just a Computer Game Right? An Interpretative Phenomenological Analysis of Online Gaming Addiction "International Journal of Mental Health and Addiction 4:205-216.

Clark, David. 1996. Urban World/Global City. New York: Routledge.
Clark, William A. V. 2002. "Monocentric to Polycentric: New Urban Forms and Old Paradigms." Pp. 141-154 in A Companion to the City, edited by G. Bridge, Sophie Watson. New york: Blackwell.

Cogburn, Jon, Mark Silcox. 2009. Philosophy Through Video Games. New York: Routledge.

Colombijn, Freek, Aygen Erdentug. 2002. "Urban Space and Ethnicity." Pp. 1-24 in Urban Ethnic Encounters: The Spatial Consequences, edited by F. C. Aygen Erdentug. New York: Routledge.

Dahlberg, Lincoln. 2011. Re-considering Digital Democracy: An Outline of Four 'Positions' New Media \& Society. (Forthcoming).

Daniels, Thomas L. 1999. When City and Country Collide: Managing Frowth in the Metropolitan Fringe. Washington, DC: Island Press.

Deutsch, Karl. 1953. Nationalism and Social Communication. Cambridge: MIT Press.

Donald, James. Imagining the Modern City. Minneapolis: University of Minnesota Press.

Durkheim, Emile. [1897] 1997. Suicide. New York: Free Press.

Ellison, Nicole, Charles Steinfield, Cliff Lampe. 2007. "Students' Use of Online Social Network Sites." Journal of ComputerMediated Communication 12:1143-1168.

Frank, Thomas. 2004. What's the Matter with Kansas?: How Conservatives Won the Heart of America. New York: Henry Holt.

Gellner, Ernest. 1983. Nations and Nationalism. Oxford, England: Basil Blackwell Publisher LImited.

Gerschenkron, Alexander. 1962. Economic Backwardness in Historical Perspective. Cambridge: Harvard University Press.

Goffman, Erving. 1959. The Presentation of Self in Everyday Life. New York: Anchor Books.

Graham, Stephen, Simon Marvin. 2001. Splintering Urbanism: Networked Infrastructures, Technolgoical Mobilities and the Urban Condition. New York: Routledge.

Gramsci, Antonio. 1992. Prison Notebooks. Translated by J. A. Buttigieg. New York: Columbia University Press.

Groth, Jacqueline, Eric Corijn. 2005. "Reclaiming Urbanity: Indeterminate Spaces, Informal Actors and Urban Agenda Setting." Urban Studies 42:503-526.

Hindman, Matthew Scott. 2009. The Myth of Digital Democracy. Princeton: Princeton University Press. 
Holloway, Lewis, Phil Hubbard. 2001. People and Place: The Extraordinary Geographies of Everyday Life. Upper Saddle River, NJ: Prentice Hall.

Horkheimer, Max. 2002. "Authority and the Family." in Critical Theory Selected Essays. New York: Continuum.

Humble, Rod. 2004. “Inside EverQuest.” Game Developer 11:18-26.

Inkeles, Alex, David Smith. 1974. Becoming Modern. Cambridge: Harvard University Press.

Ito, Mizuko. 2008. "Introduction." Pp. 1-14 in Networked Publics, edited by K. Varnelis. Cambridge, MA: MIT Press.

Jenkins, Henry. 2006a. Convergence Culture: Where Old and New Media Collide. New York: New York University Press.

Jenkins, Henry. 2006b. Fans, Bloggers, and Gamers: Exploring Participatory Culture. New York: New York University Press.

Kaika, Maria, Erik Swyngedouw. 2000. "Fetishizing the Modern City: The Phantasmagoria of Urban Technological Networks." International Journal of Urban and Regional Research 24:120-138.

Kasarda, John D. 1995. "Industrial Restructuring and the Changing Location of Jobs." in State of the Union: Economic Trends, edited by R. Farley. New York: Russell Sage Foundation.

Lefebvre, Henri. 1991. The Production of Space. Malden, MA: Blackwell.

Lim, Merlyna, Mark E. Kann. 2008. "Politics: Deliberation, Mobilization, and Networked Practices of Agitation."Pp. 77-108 in Networked Publics, edited by K. Varnelis. Cambridge, MA: MIT Press.

Lipset, Seymour Martin. 1959. Political Man. Garden City: Doubleday.

Lofland, L.H. 1998. The Public Realm: Exploring the City's Quintessential Social Territory. New York: Aldyne de Gruyter.

Lynch, Kevin 1960. The Image of the City Cambridge: MIT Press.

Marinetti, F.T. 2006. Critical Writings, Edited by D. Thompson. New York: Farrar, Straus, and Giroux.

Marx, Karl. 1978. "The Manifesto of the Communist Party." Pp.469-500 in The Marx-Engels Reader, edited by R. Tucker. New York: Norton \& Company.

Marx, Karl. [1867] 1990. Capital vol. 1. Translated by B. Fowkes. New York: Penguin Books.

Marx, Karl. [1846] 1999. The German Ideology. New York: International Publishers.

Marx, Karl. [1848] 2008. The 18th Brumaire of Louis Bonaparte. Rockville: MD: Wildside Press.

McKibben, Bill. [1989] 2006. The End of Nature. New York: Random House.
Miner, Horace. 1952. “The Folk-Urban Continuum.” American Sociological Review 17:529-37.

Mitchell, William J. 1995. City of Bits: Space, Place, and the Infobahn. Cambridge, MA: MIT Press.

Mumford, Lewis. 1961. The City in History. Orlando, FL: Harcourt, Inc.

Ng, Brian D., Peter Wiemer-Hastings. 2005. "Addiction to the Internet and Online Gaming." CyberPsychology \& Behavior $8: 110-113$.

Pollan, Michael. 2006. The Omnivore's Dilemma: A Natural History of Four Meals. New York: Penguin.

Rheingold, Howard. 2000. The Virtual Community: Homesteading on the Electronic Frontier. Cambridge: MA: The MIT Press.

Robbins, Kevin, Mark Hepworth. 1988. "Electronic Spaces: New Technologies and the Future of Cities "Futures 20:155-176.

Rousseau, Jean-Jacques. [1762] 2003. Émile: Or Treatise on Education. New York: Prometheus Books.

Russell, Adrienne, Mizuko Ito, Todd Richmond, Marc Tuters. 2008. "Culture: Media Convergence and Networked Participation.” Pp. 43-76 in Networked Publics, edited by K. Varnelis. Cambridge, MA: MIT Press.

Saunders, Peter. 1995. Social Theory and the Urban Question. New York: Routledge.

Schulzke, Marcus. 2011. "How Games Support Associational Life: Using Tocqueville to Understand the Connection." Games and Culture. (Forthcoming).

Short, John R. 1991. Imagined Country: Environment, Culture, Society. New York: Routledge.

Sibley, D. 1995. Geographies of Exclusion: Society and Difference in the West. New York: Routledge.

Soja, Edward W. 1989. Postmodern Geographies: The Reassertion of Space in Critical Social Theory. New York: Verso.

Steinkuehler, Constance, Dmitri Williams. 2006. "Where Everybody Knows Your (Screen) Name: Online Games as "Third Places"." Journal of Computer-Mediated Communication 11:885-909.

Taylor, T.L. 2006. Play Between Worlds: Exploring Online Game Culture. Cambridge: MIT Press.

Tittle, Charles R., Harold G. Grasmick. 2001. "Urbanity: Influences of Urbanness, Structure, and Culture." Social Science Research 30:313-335.

Varnelis, Kazys, Anne Friedberg. 2008. "Place: The Networking of Public Space." Pp. 15-42 in Networked Publics, edited by K. Varnelis. Cambridge, MA: MIT Press. 
Virilio, Paul. 1999. Politics of the Very Worst. Cambridge: MA: Semiotext(e).

Williams, Raymond. 1975. The Country and the City. New York: Oxford University Press.

Wilson, Thomas C. 1991. "Urbanism, Migration, and Tolerance: A Reassessment.” American Sociological Review 56:117-123.

Wirth, Louis. 1938. "Urbanism as a Way of Life." American Journal of Sociology 44.

Wolch, Jennifer. 2002. “Anima Urbis.” Progress in Human Geography 26:721-742.

Wolfendale, Jessica. 2007. "My Avatar, My Self: Virtual Harm and Attachment." Ethics and Information Technology 9:111-119.

Wolff, Robert Paul. 1968. The Poverty of Liberalism. New York: Beacon Press.

Yee, Nick. 2006a. “The Demographics, Motivations, and Derived Experiences of Users of Massively Multi-User Online Graphical Environments." Presence 15:309-329.
Yee, Nick. 2006b. "The Labor of Fun: How Video Games Blur the Boundaries of Work and Play." Games and Culture 1:68-71.

Young, Craig, Martina Diep, Stephanie Drabble. 2006. "Living with Difference? The 'Cosmopolitan City' and Urban Reimaging in Manchester, UK.” Urban Studies 43:1687-1714.

Zha, Wei, David D. Perlmutter. "Blogs as Stealth Dissent?: "Eighteen Touch Dog Newspaper" and the Tactics, Ambiguity, and Limits of Internet Resistance in China" Pp. 261-276 in International Media Communication in a Global Age, edited by Guy J. Golan, Thomas Johnson, Wayne Wanta. New York: Routledge.

Zernike, Kate. 2010. Boiling Mad: Inside Tea Party America. New York: Henry Holt.

Zukin, Sharon. 1998. "Urban Lifestyles: Diversity and Standardisation in Spaces of Consumption." Urban Studies 35:825-839. 
